\title{
PENGEMBANGAN LITERASI DAN PELATIHAN MENINGKATKAN KEPERCAYAAN DIRI ANAK DI TAMAN BACA KAMPUNG NAGROG SUBANG
}

\author{
Dani Dagustani \\ dagustani@yahoo.com \\ Gatot Iwan Kurniawan \\ gatot.iwan@ekuitas.ac.id
}

Kannya Purnamahatty Prawirasasra

kannya.prawirasasra@ekuitas.ac.id

\section{SEKOLAH TINGGI ILMU EKONOMI EKUITAS}

\begin{abstract}
ABSTRAK
Kegiatan pengabdian pada masyarakat yang dilakukan bertujuan untuk menangani perrmasalahan yang di alami oleh mitra. Hasil survey awal didapat bahwa taman baca yang ber ada di Kampung Nagrog Desa Palasari Kecamatan Ciater Subang menghadapi beberapa permasalahan yaitu kurangnya pengetahuan mengenai manajeman pengelolaan, kurangnya literasi buku yang ada juga tingkat kepercayaan diri anak-anak anggota taman bacaan yang masih kurang. Solusi yang dilakukan yaitu dengan melakukan konsultasi manajemen tata kelola organisasi, penambahan litarasi buku dan pelatihan peningkatan kepercayaan diri anak. Hasil yang didapat melalui konsultasi tata kelola, manajemen yang ada sudah lebih terarah dengan adanya tahapan perencanaan jangka panjang yang akan direalisasi dengan perencanaan jangka pendek. Adanya pelatihan pada anak di taman baca memberikan suatu pengalaman yang secara tidak langsung menumbuhkan kepercayaan diri dan adanya tambahan literasi buku dapat meningkatkan minat anak untuk terus berkunjung ke taman baca.
\end{abstract}

Kata kunci: Taman Baca; Literasi; Pelatihan

\section{PENDAHULUAN}

Pembangunan yang tidak merata memberikan dampak diberbagai sektor pembangunan. Pembangunan itu sendiri akan lebih terasa di daerah perkotaan dibandingkan dengan daerah pedesaan. Pemerintah menyadari kondisi ini dan sudah berusahaa mengeluarkan berbagai kebijakan serta tindakan untuk mampu meratakan pembangunan ke daerah pedesaan. Dalam pelaksanaan kebijakan sering terbentur dengan berbagai macam permasalahan diantaranya, yaitu dengan prosedur penerapaan kebijakan yang panjang yang dapat memicu terjadinya penyelewengan oleh pihak-pihak terkait. Tindakan tersebut terlaksana dengan mudah terlebih lagi di dorong dengan kurangnya pengetahuan masyarakat di daerah pedesaan.

Tidak meratanya pembangunan ini diantaranya terlihat melalui tingkat pendidikan yang ada di pedesaan. 
Perkembangan pendidikan dunia akan terlihat sangat timpang jika dibandingkan dengan perkembangan dunia pendidikan di pedesaan, sehingga akan sangat sulit untuk mengejar standar pendidikan yang ada sekarang ini. Untuk dapat mengejar ketertinggalan maka harus ada upaya baik dari pemerintah serta masyarakat lokal untuk berpartisipasi melalui berbagai macam program sehingga dapat mengurangi gap yang ada. Peran masyarakat dalam hal ini jika melihat pada Salah satu program yang dapat menunjang pendidikan dipedesaan yaitu mengembangkan budaya literasi. Dalam hal ini pemerintah sudah berupaya untuk mendukung budaya literasi ini melalui RUU Sistem Pembukuan dan RUU Pemajuan Kebudayaan dimana isi dari RUU sistem pembukuan mengusung semangat mewujudkan buku yang murah, bermutu dan murah yang diharapkan akan menunjang kemajuan kebudayaan yang ada di

Indonesia,(http://epaper1.kompas.com/kom pas/books/kompas/2017/20170428kompas/ \#/11/ diunduh pada tanggal 15 Juli 2017).

Berdasarkan Undang-Undang

Republik Indonesia Nomor 3 Tahun 2017 Tentang Sistem Perbukuan, Pasal 8, ayat 1 dan 2 menjelaskan bahwa masyarakat berhak untuk memperoleh kesempatan untuk berperan serta dalam Sistem Perbukuan dan juga berhak mendapatkan kemudahan akses terhadap Buku Bermutu dan informasi perbukuan. Dari pernyataan tersebut jelas bahwa adanya hak yang dimiliki oleh masyarakat untuk mendapatkan kesempatan membaca bukubuku bermutu, dimana dalam hal ini sangat dibutuhkan peran pemerintah dalam mengenalkan, mensosialisasikan hingga membuat suatu sistem pengaturan proses yang dapat memudahkan masyarakat untuk mengakses buku maupun informasi. Dalam undang-undang tersebut juga menjelaskna dibutuhkannya peran dari masyarakat dalam mengembangkan budaya literasi.

Sebagai contoh yang secara tidak langsung merupakan gambaran dari peran masyarakat dalam mengembangkan budaya literasi bisa terlihat pada upaya yang dilakukan oleh pemuda yang ada di Kampung Nagrog Desa Palasari Kecamatan Ciater Subang, berinisiai untuk memberikan ide, tenaga dan prasarana dalam bentuk pendidikan luar sekolah serta taman baca sebagai bentuk kepedulian mereka terhadap tempat kelahiran mereka. Kegiatan yang meraka lakukan secara tidak sadar sesuai dengan Undang-Undang Republik Indonesia Nomor 3 Tahun 2017 Tentang Sistem Perbukuan, Pasal 11, Ayat 2, yang isinya menekankan bahwa masyarakat berkewajiban memberikan dukungan terhadap terciptanya masyarakat belajar, masyarakat gemar membaca, dan masyarakat gemar menulis.

Beberapa penggagas program ini yatu pemuda asal daerah yang sudah lulus lulus kuliah dan bekerja, ketika melihat kondisi pendidikan yang ada di desa asala mereka, merasa tergerak untuk membuat program yang dapat meningkatkan kapasitas generasi muda yang ada di desa agar mampu berkompetisi dengan kebutuhan pendidikan saat ini. Keinginan mereka juga berkaca ketika mereka diusia muda merasa bahwa banyak kegiatan di desa mereka yang yang menjurus kearah negatif. Dengan dibentuknya pendidikan luar sekolah serta taman baca diharapkan menjadi suatu sarana dan tempat berkumpulnya anak-anak sehingga akan menggiring mereka dengan hal-hal yang positif dan berguna sebagai bekal mengejar cita-cita. 
Kegiatan mereka dapat tidak terlaksana dengan baik jika proses penetapan visi dan misi serta tata kelola yang diterapkan tidak searah antara keinginan untuk merubah suatu budaya yang negatif menjadi positif yang mampu meningkatkan kapasitas anak melalui adanya taman baca. Selain itu sarana yang kurang serta kurangnya program kegiatan yang menarik di khawatirkan bisa menurunkan niat anak-anak untuk terus mengunjungi taman bacaan. Melihat kondisi diatas maka harus dibenahi dulu organisasi yang ada sesuai dengan sistem pengelolaan taman bacaan yang baik yang sejalan dengan tujuannya.Selain itu pengurus taman bacaan juga harus terus berupaya untuk meningkatkan terus prasarana yang ada melalui kerjasama dengan pihak-pihak terkait.

Pendidikan luar sekolah serta taman baca ini mereka namakan Saung Linuhung Paringgha. Tempat ini sudah berjalan selama 4 bulan dimana pesertanya lebih kurang berjumlah 20 orang dengan usia antara 7-13 tahun. Target utama mereka saat ini yaitu untuk menumbuhkan minat membaca untuk para anggotanya. Materi yang diajarkan selama ini yaitu pengenalan komputer, bahasa inggris, bimbingan belajar dan pembentukan karakter dan jadwal yang ada saa ini yatiu pada hari senin, rabu dan jumat untuk materi pengenalan komputer, bahasa inggris dan bimbingan belajar sedangkan hari minggu diisi untuk pembentukan karakter melalui permainan tradisional dan mereka menyebutnya Kaulinan Tradisional.

Dari survai awal yang dilakukan didapat beberapa kendala diantaranya yaitu masih kurangnya tata kelola organisasi berdasarkan manajemen yang baik dimana diketahui visi dan misi belum jelas disusun dan tertulis, belum adanya tujuan yang jelas serta strategi jangka panjang dan jangka pendek, program-program yang ada sebagai penjabaran misi dan masih berupa ide-ide yang belum tersusun dengan baik, jumlah buku yang relatif sedikit jika dibandingkan dengan rak maupun dengan ruangan yang ada. Agar suatu organisasi bisa berjalan dengan baik maka harus jelas dulu penetapan visi dan misi organisasi sehingga akan terbentuk tujuan dan objektif sebagai penjabaran misi setelah itu dibentuklah strategi-strategi yang implementasinya dilaksanakan dengan program-program yang menarik.

\section{METODOLOGI PELAKSANAAN}

Berdasarkan permasalahan yang ada pada mitra serta solusi yang akan diberikan dalam kegiatan pengabdian pada masyarakat maka proses kegiatan yang akan dilaksanakan dibuat berdasarkan alir proses yang dapat dilihat pada Gambar 2.1.

\section{Keterangan :}

1. Survey kondisi mitra, yaitu untuk mengetahui secara jelas kondisi mitra berkenaan dengan permasalahan serta kebutuhan di Taman Buku Kampung Nagrog Desa Palasari Kecamatan Ciater Subang.

2. Pada tahap ini sudah akan diputuskan program apa saja yang diberikan kepada mitra. Selain itu juga akan ditentukan hari serta berapa lama pelatihan akan dilakukan

3. Pembuatan bentuk pelatihan, dimana pada tahap ini bentuk dibuat dengan format interaktif dalam bentuk permainan, menggambar, bercerita serta melihat video. Bahan pelatihan disusun dengan menggunakan literasi buku-buku 
terkait, pencarian video melalui internet. Sedangkan konsultasi yang dilaksanakan bersifat diskusi mengenai identifikasi kondisi saat ini serta penyusunan strategi kedepan dari organisasi. Pada tahap ini juga tim membeli buku yang seuai dengan mina anak-anak anggota taman baca sebagai upaya menambah literasi yang ada.

4. Pada tahap ini dilakukan kegiatan penyerahan buku ke mitra setelah itu setelah itu tim melaksanakan pelatihan untk meningkatkan kepercayaan diri anak-anak anggota taman baca.
5. Pada tahap melanjutkan kegiatan ditahap sebelumnya, yaitu pelatihan meningkatkan kepercayaan diri anak dan dilanjutkan dengan konsultasi mengenai tata kelola manajemen organisasi.

6. Pembuatan laporan mengenai hasil dari penyerahan buku, pelatihan dan konsultasi sebagai data untuk pengembangan program lebih lanjut.

7. Pada tahap ini pelaksanaan proses pelatihan selesai sesuai dengan hasil yang dinginkan.

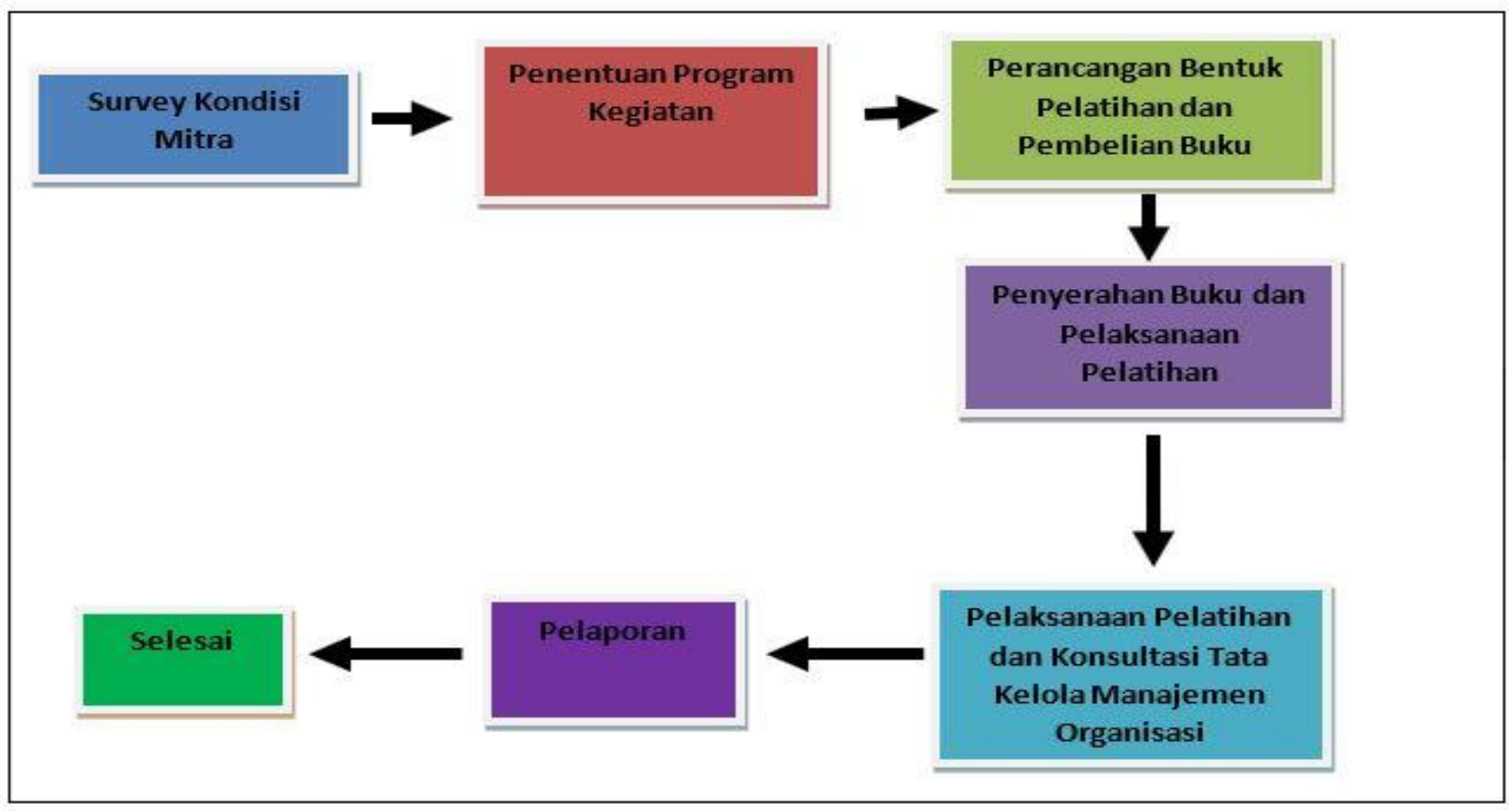

Gambar 3.1 Proses Pelaksanaan Pengembangan Literasi Taman Baca dan Pelatihan

Menumbuhkan dan Menngkatkan Kepercayaan Diri Anak

\section{HASIL DAN LUARAN}

\subsection{Hasil}

Pemberian buku bacaan untuk menambah literasi taman baca dan Pelaksanaan Pelatihan ini mampu membarikan suatu hasil sebagai berikut :
1. Meningkatkan rasa ingin membaca serta keinginan berjunjung karena buku yang diberikan sesuai dengan minat dari para anggota dimana buku yang mereka inginkan sudah di survey terlebih dahulu.

2. Memakmurkan taman baca dengan kehadiran para anggota serta bisa 
meningkatkan jumlah anggota yang baru

3. Meningkatkan bentuk sosialisasi serta interaksi antar para anggota dengan meningkatnya minat berkunjung ke taman baca

4. Memiliki tingkat percaya diri yang semakin baik terlihat pada pelatihan lanjutan dimana peserta sudah mampu mampu mempresentasikan hasil karyanya di hadapan peserta lainnya dengan cara yang tidak kaku dengan pendekatan yang berbeda.

Selain itu dengan adanya konsultasi mengenai tata kelola suatu organisasi maka para pengurus sudah mampu

1. Menentukan visi dan misi suatu organisasi

2. Membuat rencana jangka pendek dan panjang

3. Menentukan strategi pengembangan taman baca

4. Membuat program-program yang diturunkan dari strategi yang sudah ditetapkan

\subsection{Luaran}

Luaran yang dicapai dalam pelaksanaan kegiatan ini adalah Taman bacaan "Saung Linuhung Paringgha" mendapatkan donasi buku bacaan sebagai salah satu bentuk untuk meningkatkan minat baca di usia dini. Penambahan soft skill anak-anak taman bacaan dan Pengembangan pengetahuan tentang tata kelola organisasi.

\section{KESIMPULAN DAN SARAN}

\subsection{Kesimpulan}

3. juga program-program pengembangan untuk terus mendukung minat anak untuk terus belajar

4. Perlu dilakukan konsultasi lebih lanjut mengenai tata kelola organisasi secara berkesinambungan.
Dari seluruh rangkaian kegiatan yang di laksanakan di Taman bacaan "Saung Linuhung Paringgha", dapat disimpulkan bahwa:

1. Dengan adanya peningkatan sarana melalui penyerahan buku yang sesuai dengan minat anak akan meningkatkan ketertarikan anak untuk membaca dan juga bertambahnya minat anak untuk terus berkunjung ke taman baca

2. Dengan dilakukan pelatihan dengan dua tahapan di dapat bahwa peserta menunjukkan peningkatan kepercayaan diri dalam mempresentasikan karyanya dimana presentasi sebelumnya terlihat kaku dan enggan dihadapan peserta lainnya setelah pelatihan terlihat lebih antusias dan merasa nyaman ketika presentasi dengan mencoba menerapkan teknik-teknik yang diajarkan ketika pelatihan.

3. Pengurus sudah mendapatkan gambaran mengenai arah dari organisasi yang sudah didirikan dan mendapatkan masukan mengenai tata kelola organisasi berupa rancangan sederhana yang bisa dikembangkan lebih lanjut oleh manajeman taman baca.

\subsection{Saran}

Berikut adalah beberapa saran yang diperoleh dari seluruh rangkaian kegiatan:

1. Terus meningkatkan sarana dan prasarana yang ada sehingga bisa mempercepat pencapaian tujuan dari pendirian taman baca

2. Dibutuhkan kegiatan belajar dan mengajar yang berkesinambungan dan 


\section{DAFTAR PUSTAKA}

http://epaper1.kompas.com/kompas/books/

kompas/2017/20170428kompas/\#/1

1/ diunduhpada tanggal 15 Juli 2017).
Undang-Undang Republik Indonesia Nomor 3 Tahun 2017 Tentang Sistem Perbukuan. 